\title{
Neutronic and Thermal/Fluid Design and Instrumentation for the FLIQURE Experiment
}

J. W. Sterbentz

J. E. O'Brien

R. A. Anderl

G. R. Smolik

D. A. Petti

K. A. McCarthy

September 2000

Idaho National Engineering and Environmental Laboratory Bechtel BWXT Idaho, LLC 


\title{
Neutronic and Thermal/Fluid Design and Instrumentation for the FLIQURE Experiment
}

\author{
J. W. Sterbentz \\ J. E. O'Brien \\ R. A. Anderl \\ G. R. Smolik \\ D. A. Petti
}

K. A. McCarthy

September 2000

Idaho National Engineering and Environmental Laboratory Idaho Falls, Idaho 83415

\author{
Prepared for the \\ U.S. Department of Energy \\ Office of Sciences \\ Under DOE Idaho Operations Office \\ Contract DE-AC07-99ID13727
}




\section{SUMMARY}

A preliminary design is presented for the FLIQURE or Fusion LIQUid Release Experiment. This experimental system is designed to measure the mobilization of tritium, fluorine, and other constituents in molten Flibe following trace neutron irradiation at fusion-relevant temperatures $\left(500-1000^{\circ} \mathrm{C}\right)$. Trace neutron irradiation is achieved using a spontaneous fission ${ }^{252} \mathrm{Cf}$ source that produces a uniform concentration of tritium in the Flibe. The experimental goals aim to better understand the mechanisms, mobilization rates, and physiochemical forms of tritium mobilized from the Flibe along with other potentially detectable radioactive isotopes and toxicmaterial species under inert-gas, air, and steam-ingress conditions. System design details are discussed which include neutronic studies to optimize tritium production, thermal design to maintain and isolate molten Flibe, and instrumentation to meet experimental goals. 


\section{ACKNOWLEDGEMENTS}

This work is supported by the U. S. Department of Energy, Office of Sciences, under the DOE Idaho Operations Contract DE-AC07-99ID132727. The authors wish to thank Stan Schuetz for his efforts in preparing the glovebox and fume hood for the unirradiated experiments. We would also like to thank Jodie Boyce for his assistance in setting up the heater assemblies for bake-out and preliminary testing. 


\section{CONTENTS}

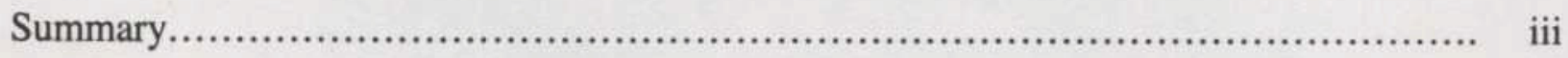

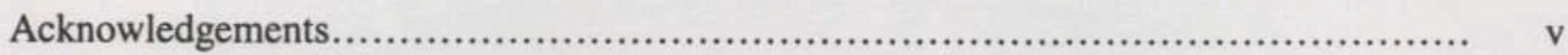

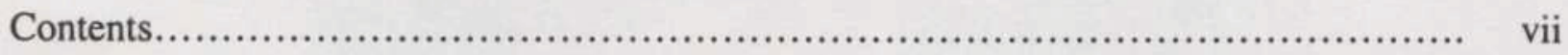

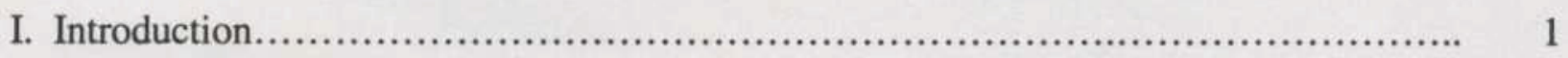

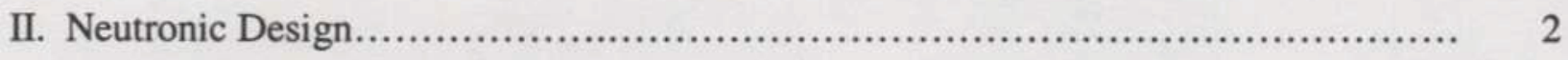

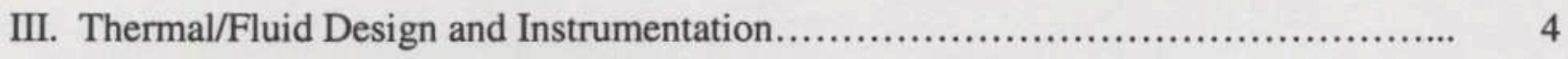

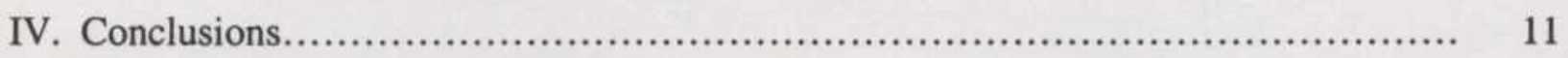

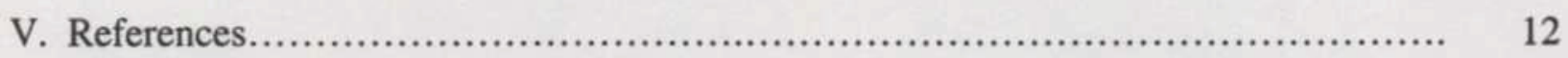




\section{INTRODUCTION}

The molten salt known as Flibe $\left(\mathrm{LiF}-\mathrm{BeF}_{2}\right)$ has many attractive chemical and physical properties $^{1-4}$ that make it a leading candidate material for fusion reactor applications. It has high chemical stability at elevated temperatures, breeds tritium via neutron interaction, sustains no radiation damage in the liquid phase, possesses low vapor pressure, low induced activation, low viscosity, low electrical conductivity, small density change on melting, and is relatively inert in air and water (non-combustible). Because of these properties, Flibe has been proposed for use in magnetic fusion reactors ${ }^{4}$ as a radiation shield, coolant, and plasma-facing, renewable surface against plasma in high-flux core regions. In inertial-confinement reactors, Flibe has been proposed $^{5}$ as a blast and neutron damage shield to protect the first wall. In both types of reactors, Flibe would breed additional tritium or fusion reactor fuel.

An area of concern in the use of Flibe is the very low solubility of tritium in the molten salt. Small concentrations of tritium in Flibe will have high chemical activity and under abnormal reactor operating conditions may present opportunities for the tritium to escape the reactor system to the environment. From a fusion safety standpoint, understanding the mechanisms by which tritium can mobilize within the Flibe and rates at which it can exit the Flibe surface are of vital importance.

The FLIQURE or Fusion LIQUid Release Experiment has been designed to specifically study the mobilization behavior of tritium in molten Flibe $\left(2 \mathrm{LiF}, \mathrm{BeF}_{2}\right)$ under controlled low-level neutron irradiation at elevated temperatures $\left(\sim 500-1000^{\circ} \mathrm{C}\right)$ and under a variety of gas-Flibe surface interface conditions, e.g. inert-gas, air, and steam-ingress. Tritium produced via neutron interaction with both lithium $\left({ }^{6} \mathrm{Li},{ }^{7} \mathrm{Li}\right)$ and beryllium $\left({ }^{9} \mathrm{Be}\right)$ atoms in the Flibe will tritiate the Flibe in a manner similar to that expected in a fusion reactor core. Neutron interaction with the fluorine atoms will produce a variety of potentially detectable gamma-ray-emitting radioactive nuclides that can be measured and provide estimates of fluorine gas production and mobilization rates out of the Flibe. In addition to the physical and chemical forms of tritium, the experiment will also consider other radioactive isotopes and toxic-material species generated in the Flibe during irradiation. Tritium permeability rates through various fusion-reactor structural materials are also of interest as is the mobilization of toxic materials, i.e. Be/Be-compound and F/Fcompound aerosols.

The preliminary FLIQURE design presented here utilizes a cylindrical-pot test cell filled with molten Flibe surrounded by heaters, insulation, a neutron moderator/reflector and shield. A spontaneous-fission neutron source $\left({ }^{252} \mathrm{Cf}\right.$ oxide) is situated beneath the pot with a fixed neutron emission rate. To efficiently use the source neutrons, the initial design objective was to maximize the tritium production rate in the Flibe. This objective required parametric neutronic studies involving the Flibe geometry, selection of optimal neutron-moderating materials and thicknesses, and source location. Results of the parametric studies are presented here.

Thermal and instrumentation design aspects of the experiments will also be presented. During the experimental program, the test cell containing the molten salt will be heated to temperatures as high as $1000^{\circ} \mathrm{C}$. The test cell will include four penetrations (1) a mobilization gas stream (air, steam, $\left.\mathrm{He}, \mathrm{N}_{2}\right),(2)$ a hydrogen-permeation carrier-gas stream $\left(\mathrm{He}, \mathrm{N}_{2}\right),(3)$ an inlet line for 
introduction of small quantities of hydrogen or deuterium gas into the molten Flibe, and (4) a transfer tube for molten Flibe. Details of the thermal design and associated instrumentation will also be discussed.

\section{NEUTRONIC DESIGN}

Extensive neutronic analyses were performed in order to predict nuclear reaction rates in the Flibe and to develop FLIQURE geometry and material design options that would maximize the tritium production rate. All analyses were based on calculations using the MCNP4B neutronphoton-electron transport code 6 . Fully explicit 3D MCNP4B geometry models included the molten Flibe, pressure vessel, heaters, insulation, moderator and reflector materials, shielding, and the neutron source. Also, the following nuclear reaction rates were calculated in the Flibe: ${ }^{6} \mathrm{Li}(\mathrm{n}, \alpha){ }^{3} \mathrm{H},{ }^{7} \mathrm{Li}(\mathrm{n}, \alpha \mathrm{n}){ }^{3} \mathrm{H},{ }^{9} \mathrm{Be}(\mathrm{n}, 2 \mathrm{n}) 2 \alpha,{ }^{9} \mathrm{Be}(\mathrm{n}, \gamma){ }^{10} \mathrm{Be},{ }^{19} \mathrm{~F}(\mathrm{n}, 2 \mathrm{n}){ }^{18} \mathrm{~F},{ }^{19} \mathrm{~F}(\mathrm{n}, \alpha){ }^{16} \mathrm{~N},{ }^{19} \mathrm{~F}(\mathrm{n}, \mathrm{p}){ }^{19} \mathrm{O}$, and ${ }^{19} \mathrm{~F}(\mathrm{n}, \gamma){ }^{20} \mathrm{~F}$. In addition, the code can calculate neutron and gamma-ray dose rates for determining shielding requirements. All neutron cross section data were obtained from the Evaluated Nuclear Data Files (ENDF-5 and ENDF-6).

Initial neutronic calculations focused on the maximization of the tritium production rate in the molten Flibe with consideration given to two basic geometric pressure-vessel configurations: cylindrical annulus with a centrally located source, and cylindrical pot with source located beneath the pot. The Flibe volume, aspect ratio, and enrichment were considered in the parametrics. Molten Flibe used in the neutronics calculations was assumed to be pure $2 \mathrm{LiF}-\mathrm{BeF}_{2}$ $\left(66 \mathrm{~mole} \% \mathrm{LiF}\right.$ and $34 \% \mathrm{BeF}_{2}$ with a density of $2.04 \mathrm{~g} / \mathrm{cc}$ at $500^{\circ} \mathrm{C}$. The neutron source was chosen to be a spontaneous-fission neutron source $\left({ }^{252} \mathrm{Cf}\right.$ oxide), because preliminary estimates indicated reasonable tritium production rates and irradiation times using readily available 1-5 $\mathrm{mg}{ }^{252} \mathrm{Cf}$ sources.

The cylindrical-annulus configuration placed the source at the center and midplane of the annulus with a top, bottom, and radial reflector material surrounding the annular Flibe vessel. A variety of moderator materials were evaluated including beryllium, graphite, light water, heavy water, zirconium hydride, nickel, and polyethylene. Figure 1 shows the tritium production rate as a function of material and thickness. The beryllium reflector produced the highest tritium production rate, while the zirconium hydride and water

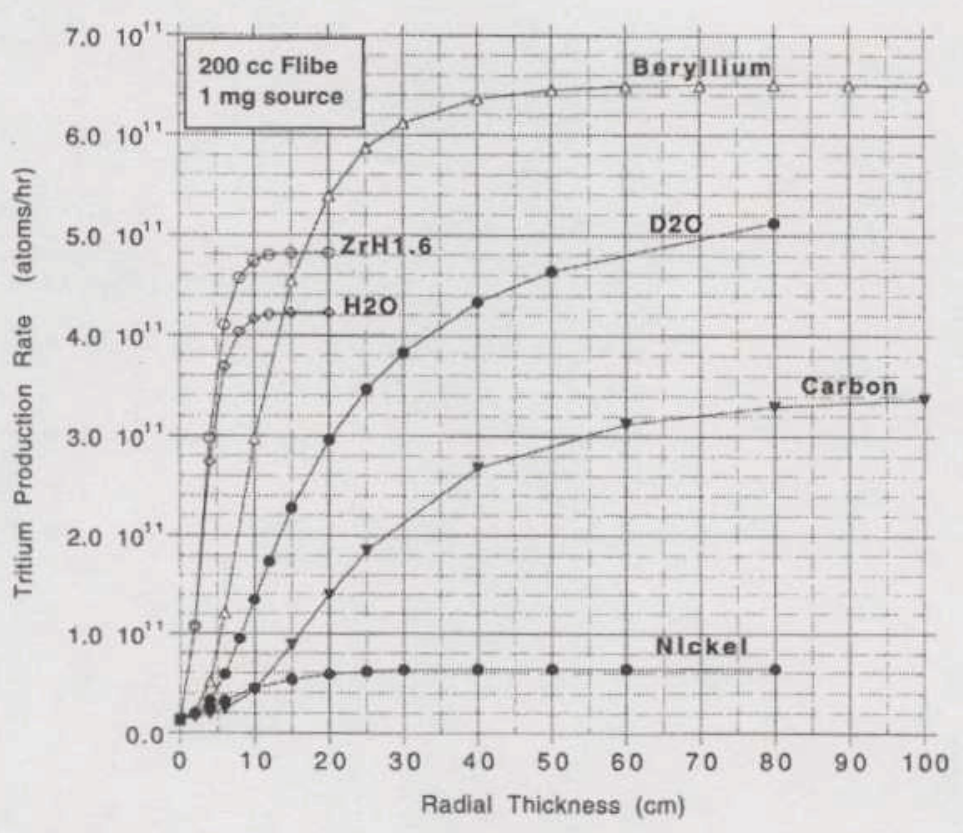

Figure 1. Tritium production rate versus reflector material and thickness. 
reflectors produced reasonable rates (30\% less), but with a much thinner reflector. Further increases in the tritium production rate were achieved by sleeving the source in a moderating material of high hydrogen density (optimal thickness for a zirconium hydride sleeve was $7.0-\mathrm{cm} \mathrm{OD)}$ ).

Despite the advantages afforded by the cylindrical-annulus configuration, the cylindrical pot design was instead adopted with the ${ }^{252} \mathrm{Cf}$ source located horizontally beneath the pot. The simplicity of the pot configuration was less costly and more amenable to instrumentation and test specimen installation, and resulted in only a $10 \%$ loss in the tritium production rate for the allberyllium reflector case. The

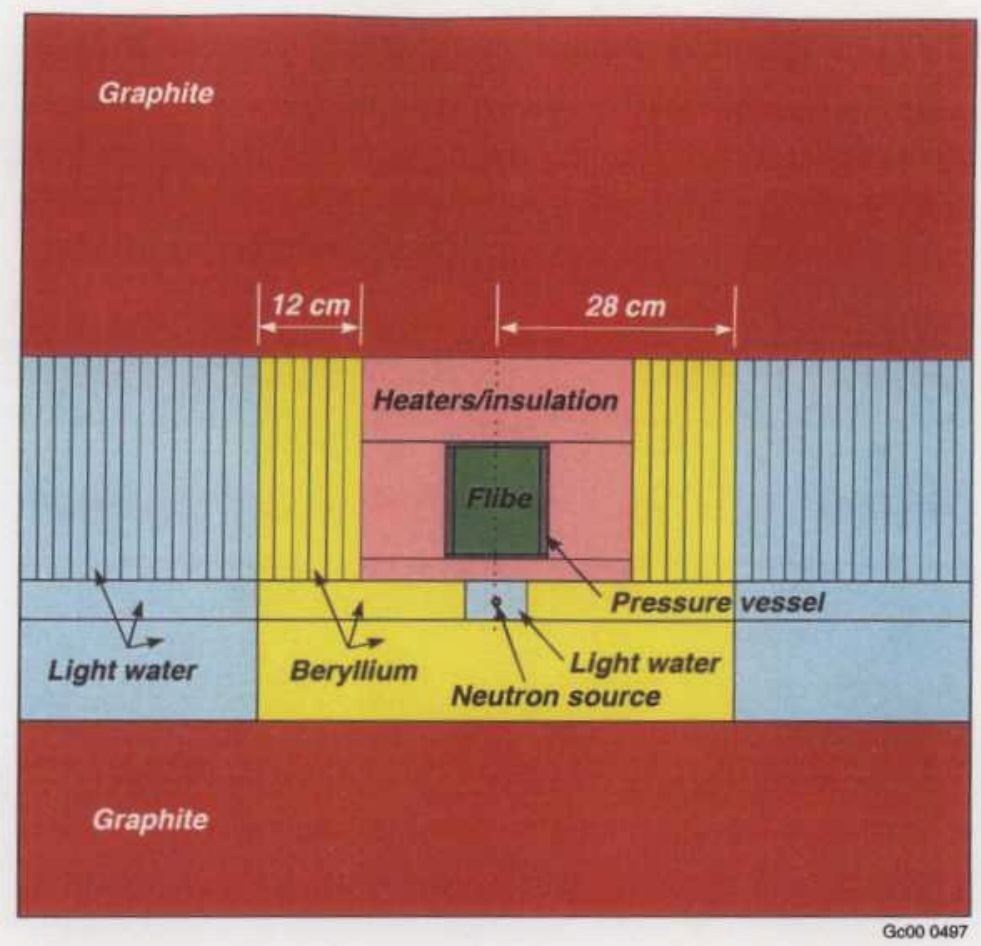

Figure 2. Optimal reflector design for the pot configuration. annular-configuration parametrics were still applicable and provided design insight for the pot configuration. However, more detailed parametric studies were needed for the now asymmetric irradiation.

Parametric calculations for the pot reflector design utilized a seven-region subdivision of the outer reflector with the radial regions surrounding the Flibe further subdivided into $2.0-\mathrm{cm}$ thick annuli. Methodical substitution of beryllium, light water, graphite, heavy water, and polyethlene were then evaluated for optimal placement and thickness. Subdivision of the outer reflector was also driven in part by need to reduce and replace beryllium. Although a beryllium reflector produced the best tritium production rate, the $40-\mathrm{cm}$ thick reflector would require 1.8 metric tons of beryllium!

Figure 2 shows one of several optimal moderator/reflector designs that could be used as a viable configuration for the cylindrical pot system. This particular design produced $\mathrm{a}+7.6 \%$ increase in the tritium production rate over the allberyllium reflector case. The bulk of this increase was the result of sleeving the source in a light water rectangular $(7.0-\mathrm{cm} \mathrm{x}$ $4.0-\mathrm{cm})$ tube for neutron thermalization. The beryllium mass requirement was
Table 1. Flibe reaction rates.

\begin{tabular}{|c|c|}
\hline REACTION & $\begin{array}{c}\text { RATE } \\
\text { (atoms/hr) }\end{array}$ \\
\hline${ }^{6} \mathrm{Li}(\mathrm{n}, \alpha)^{3} \mathrm{H}$ & $8.7 \mathrm{E}+11$ \\
\hline${ }^{7} \mathrm{Li}(\mathrm{n}, \alpha \mathrm{n})^{3} \mathrm{H}$ & $1.3 \mathrm{E}+9$ \\
\hline${ }^{9} \mathrm{Be}(\mathrm{n}, 2 \mathrm{n}) 2 \alpha$ & $4.2 \mathrm{E}+9$ \\
\hline${ }^{19} \mathrm{~F}(\mathrm{n}, 2 \mathrm{n})^{18} \mathrm{~F}$ & $\sim 5.2 \mathrm{E}+5$ \\
\hline${ }^{19} \mathrm{~F}(\mathrm{n}, \alpha)^{16} \mathrm{~N}$ & $1.9 \mathrm{E}+9$ \\
\hline${ }^{19} \mathrm{~F}(\mathrm{n}, \mathrm{p})^{19} \mathrm{O}$ & $1.2 \mathrm{E}+8$ \\
\hline${ }^{19} \mathrm{~F}(\mathrm{n}, \gamma)^{20} \mathrm{~F}$ & $1.2 \mathrm{E}+9$ \\
\hline
\end{tabular}


reduced to $157 \mathrm{~kg}$ with a Flibe volume of $1000 \mathrm{cc}$ (10-cm OD and 14.15-cm height). Table 1 provides the corresponding calculated reaction rates in the Flibe using a $1 \mathrm{mg}$ source (neutron emission rate of $2.4 \mathrm{E}+9 \mathrm{n} / \mathrm{sec}$ ). Reaction rates are scaleable to source mass. The volumeaveraged flux in the Flibe is $7.16 \mathrm{E}+6 \mathrm{n} / \mathrm{cm}^{2} / \mathrm{sec}$.

Based on the tritium production rates shown in Table 1, scaled-up for $10 \mathrm{mg}$ source, the tritium concentration in the Flibe after 20 hours of irradiation would be a factor of 100 below the predicted equilibrium tritium concentration in the proposed HYLIFE-II Flibe inventory 5 .

\section{THERMAL/FLUID DESIGN AND INSTRUMENTATION}

The test cell containing the molten salt will be fabricated from stainless steel $316 \mathrm{~L}$. For some experiments, the test cell will also include a liner of a different material, for example carbon, nickel-based alloy, or a refractory such as tantalum or molybdenum. The test cell will be heated using a ceramic-fiber radiant heater to temperatures up to $1000^{\circ} \mathrm{C}$. The heater will be surrounded by 2 -inch-thick, high-temperature ceramic-fiber thermal insulation. Outside of the insulation, the entire heated zone will be enclosed in a cylindrical water-cooled copper housing. Primary testvessel instrumentation will include a thermocouple probe immersed in the molten salt, an

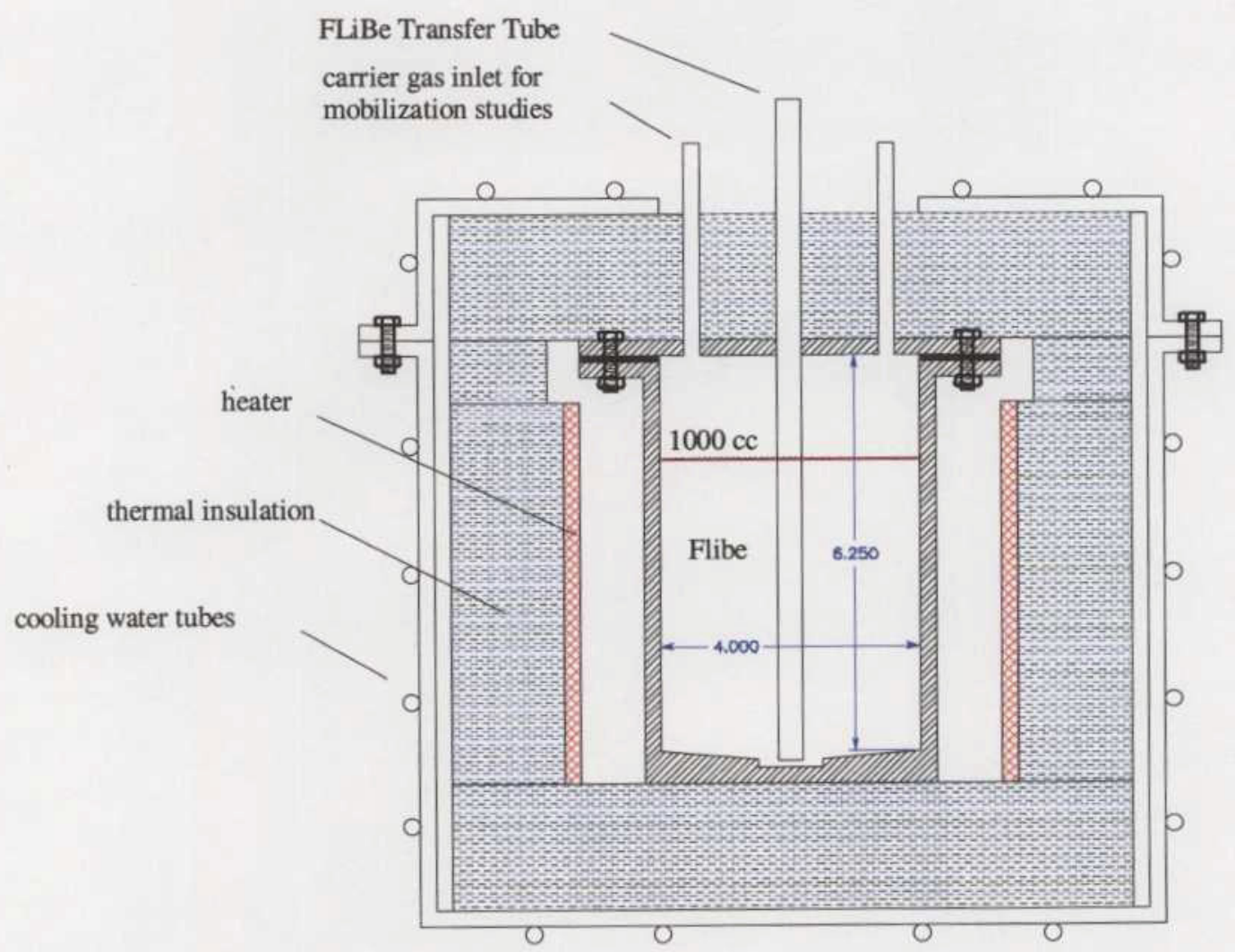

Figure 3. Primary test vessel (dimensions in inches). 

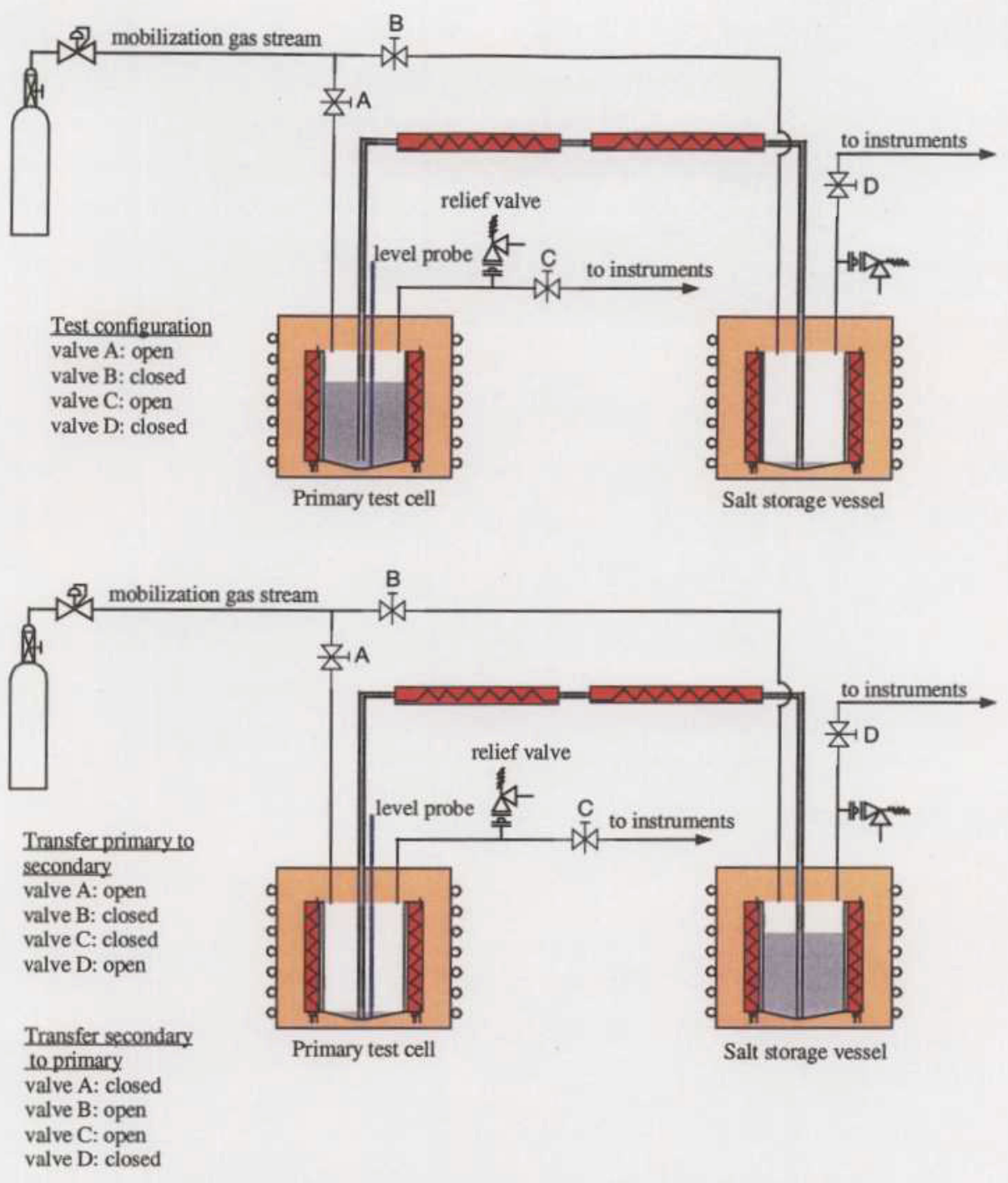

Figure 4. Two-vessel concept for molten-salt experimentation.

electrochemical probe, a liquid-level sensor, and one or more thermocouples attached to the outside of the primary vessel.

A cross-sectional scale drawing of the primary test vessel is presented in Figure 3. The internal volume of the test cell is about $1200 \mathrm{cc}$ to accommodate up to $1000 \mathrm{cc}$ of molten salt. The vessel lid will accommodate four penetrations (not all visible in the cross-section) associated with three different gas-flow streams: a mobilization gas stream (air, steam, $\mathrm{He}, \mathrm{N}_{2}$ at $\sim 1$ slpm), a hydrogen-permeation carrier-gas stream $\left(\mathrm{He}, \mathrm{N}_{2}\right.$ at $\left.\sim 100 \mathrm{sccm}\right)$, and an inlet line for introduction of small quantities $(\sim 10 \mathrm{sccm})$ of hydrogen or deuterium gas into the molten Flibe for permeation and reactivity studies. The lid configuration may be simplified for various tests, i.e. the number of penetrations may be reduced, dependent on the specific experiment requirements. The gas lines will be pre-heated to about $500{ }^{\circ} \mathrm{C}$ upstream of the primary test vessel. These lines will also be heat-traced downstream of the primary test vessel in order to avoid condensation or plateout of volatilized species and/or aerosols. One additional tubing penetration in the center of the 


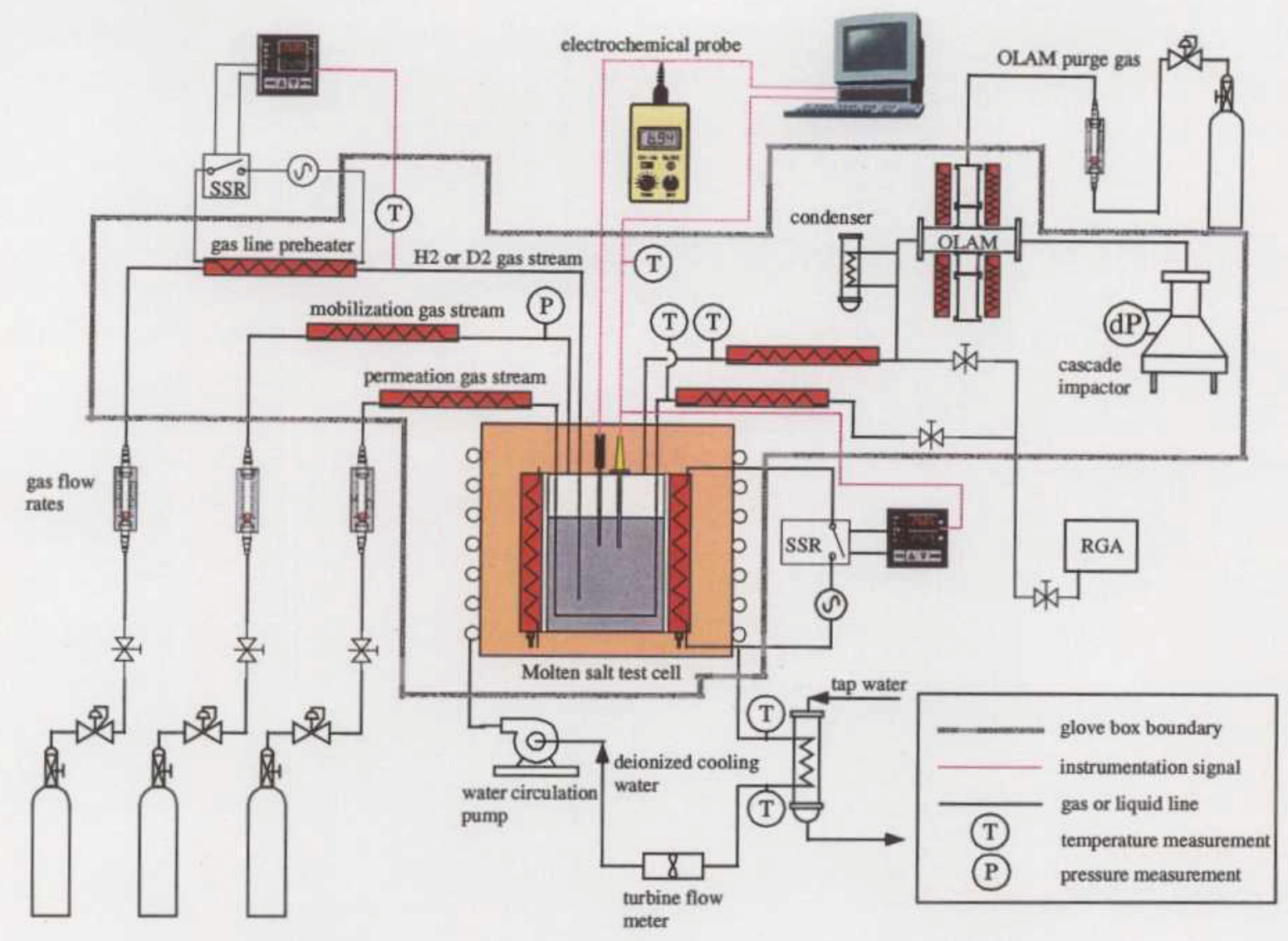

Figure 5. FLIQURE process and instrumentation diagram .

lid will allow for the transfer of molten Flibe from the primary test vessel to a secondary storage and purification vessel, similar in design and fabrication to the primary vessel. Transfer of the molten Flibe from the primary vessel to the secondary vessel will be accomplished by appropriate valving and gas pressurization, as shown in Figure 4. The Flibe transfer line will also be heated along its length using feedback-controlled cable heaters in order to avoid freezing (Flibe melting point is $460^{\circ} \mathrm{C}$ ) of the salt during the transfer process.

A process and instrumentation schematic for the FLIQURE experiment is presented in Figure 5. The schematic shows the three inlet gas streams mentioned previously. For experiments in which air or moisture are introduced into the mobilization gas stream, the supply gas line will be routed through a manifold that mixes air or moisture with the carrier gas and is equipped with sensors to measure the impurity gas concentrations prior to transport of the gas to the experimental system. The permeation setup could incorporate a single tube that passes through the molten salt, as shown in Figure 5, or a closed-end double-tube that extends into the molten salt, with inlet and outlet lines to provide for purge-gas flow through the inner volume of the closed-end tube. Each of the inert-gas and hydrogen/deuterium gas supply lines may be equipped with metal-getter purifiers to ensure the use of high-purity gas for these experiments.

Data acquisition and instrument-control programming will be accomplished using Labview software. During testing, the primary-vessel and gas-line temperatures will be feedback- 
controlled via a PID algorithm. Power switching will be accomplished using solid-state relays. A redundant independent limit controller will be used as a protective feature to de-energize the heaters in the event of a temperature rise above preset limits. Instrumentation signals for all temperatures, pressures, gas flow rates, cooling-water flow rates, etc., will be wired into a modular data-acquisition system which will be configured for these tests with a multi-channel multiplexer module (with thermocouple compensation) and a multi-channel analog-output module for heater control. Instrumentation for analysis of the mobilization and hydrogenpermeation gas streams will include a condenser unit to be used for condensation and collection of molten salt aerosol and vapor species that are transported in the gas stream flowing from the test chamber, a cascade impactor for aerosol collection and particle sizing, and a residual gas analyzer (RGA) for determination of gas composition. An on-line aerosol monitor (OLAM) may also be added for time-dependent determination of aerosol mobilization events and laserdiffraction-based particle sizing.

Because the RGA ionizer and quadrupole mass analyzer operate in a high-vacuum environment, the RGA will be coupled to the outlet gas line by a capillary or other pressure-reduction approach to permit sampling of the outlet gas stream that is at a nominal pressure of 1 atmosphere. For experiments that focus on aerosol formation and transport, this diagnostic will be used to measure carrier gas composition and non-condensable vapor species that are generated in the test chamber environment. For experiments that focus on permeation studies,

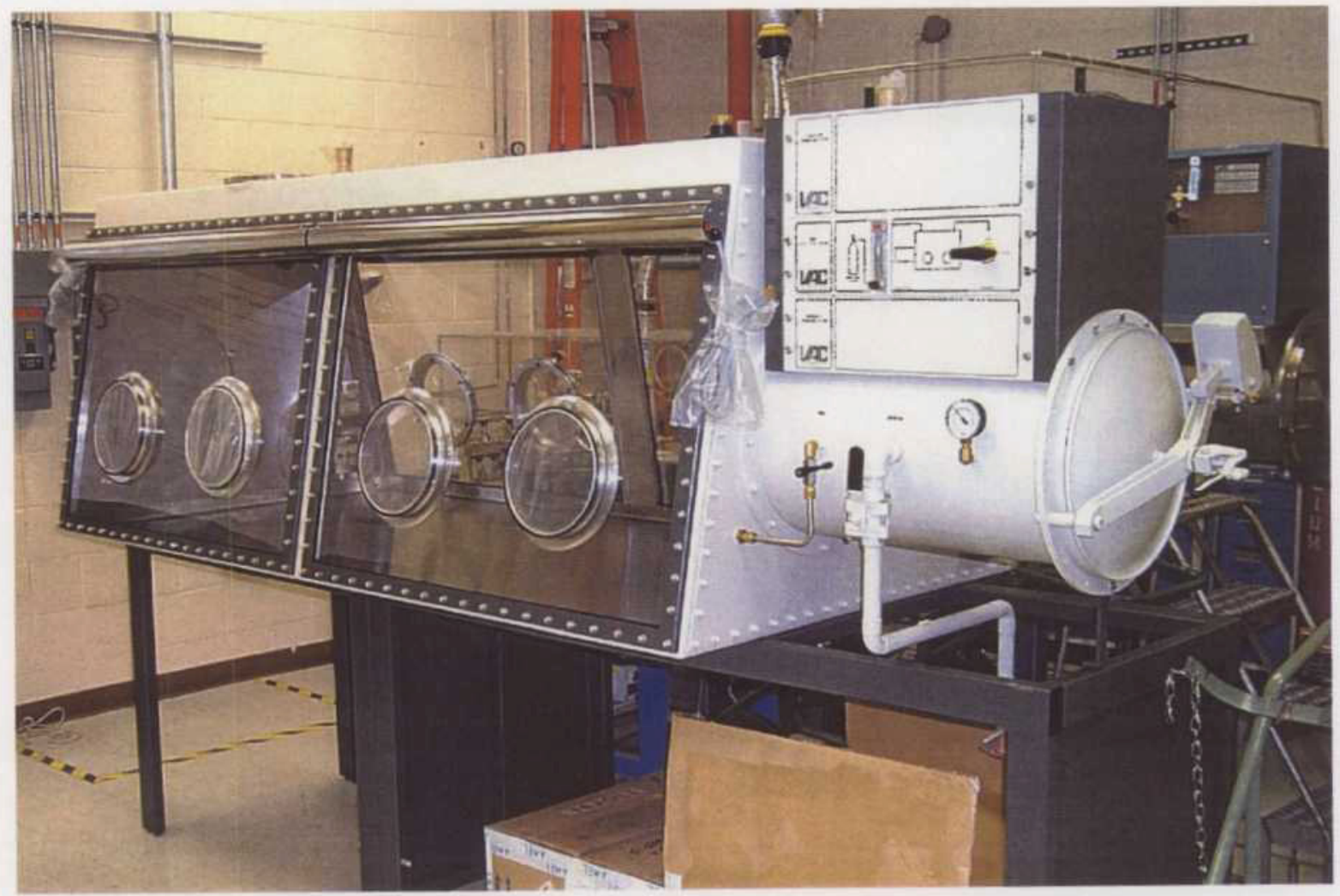

Figure 6. Glovebox for FLIQURE experiment. 
this diagnostic will be used to measure the hydrogen or deuterium that permeates from the molten salt through the permeation tube. Given the production rates presented in Table 1, we have performed an assessment of the detection sensitivity of important species in the system. We have focused on tritium, helium, free fluorine, F-18, N-16, O-19, and F-20. Assuming a 10 $\mathrm{mg}$ Cf source, a 20-hour irradiation, a flow of $100 \mathrm{cc} / \mathrm{min}$ of argon in the experiment, and complete release of each specie, the concentration of each specie in the effluent line is shown in Table 2. We will be unable to measure the helium produced via transmutation and the total free fluorine using traditional high-resolution mass spectrometry because of the low concentration in the gas stream. However, the tritium concentration is well within detectable ranges. In terms of the other radionuclides, these may also be measurable. We propose to use a getter to trap the non-hydrogenic species. This getter can then be monitored using an on-line shielded gamma ray spectrometer system to measure the F-18, F-20, O-19 and N-16 concentrations as a function of time. The tritium will pass through the getter unimpeded and can be measured on-line with a conventional ion chamber system. Integral measurements of tritium can also be performed by collection of the effluent and sampling.

Preliminary testing on the unirradiated version of FLIQURE is already under way at INEEL. The primary objective of the Molten-Salt Safety Experiment (MSSE) is to investigate the mobilization of aerosols and reaction products from high-temperature molten salts. The experiment utilizes a thermal/fluid design that is very similar to the thermal/fluid design proposed for FLIQURE. As indicated in Figure 5, most of the MSSE experimental arrangement

Table 2. Detection Sensitivity Assessment for FLIQURE

\begin{tabular}{|c|c|c|c|c|c|}
\hline $\begin{array}{l}\text { Isotope or } \\
\text { element }\end{array}$ & $\begin{array}{l}\text { Half-life } \\
\text { (s) }\end{array}$ & $\begin{array}{l}\text { Production } \\
\text { Rates } \\
\text { (atoms } / \mathrm{hr}-\mathrm{mg} \\
\text { Cf) }\end{array}$ & $\begin{array}{l}\text { Concentration } \\
\text { in Flibe } \\
\text { (atoms } / \mathrm{cc} \text { ) }\end{array}$ & $\begin{array}{l}\text { Concentration } \\
\text { in Gas }\end{array}$ & Comments \\
\hline $\mathrm{He}-4$ & stable & $8.82 \mathrm{E}+11$ & $1.76 \mathrm{E}+11$ & $\begin{array}{l}1.47 \mathrm{E}+09 \\
(\text { atoms/cc) }\end{array}$ & $\begin{array}{l}\text { Represents atom fraction } \\
\text { of } 6 \mathrm{E}-11 \text { in gas which is } \\
\text { too low to be measured }\end{array}$ \\
\hline $\begin{array}{l}\text { Total free } \\
\text { fluorine }\end{array}$ & $\ldots$ & $8.80 \mathrm{E}+11$ & $1.76 \mathrm{E}+11$ & $\begin{array}{r}1.47 \mathrm{E}+09 \\
(\text { atoms/cc) }\end{array}$ & $\begin{array}{l}\text { Represents atom fraction } \\
\text { of } 6 \mathrm{E}-11 \text { in gas which is } \\
\text { too low to be measured }\end{array}$ \\
\hline $\mathrm{H}-3$ & $3.88 \mathrm{E}+08$ & $8.71 \mathrm{E}+11$ & $1.74 \mathrm{E}+11$ & $\begin{array}{c}70.0 \\
(\mathrm{pCi} / \mathrm{cc})\end{array}$ & $\begin{array}{l}\text { Well above ion chamber } \\
\text { sensitivity }\end{array}$ \\
\hline F-18 & 6600 & $5.20 \mathrm{E}+05$ & $1.38 \mathrm{E}+04$ & $\begin{array}{c}0.33 \\
(\mathrm{pCi} / \mathrm{cc})\end{array}$ & $\begin{array}{l}\text { Positron emitter. } \\
\text { Annihilation peak from } \\
\text { beta decay can be } \\
\text { measured }\end{array}$ \\
\hline $\mathrm{N}-16$ & 7.1 & $1.90 \mathrm{E}+09$ & $5.41 \mathrm{E}+04$ & $\begin{array}{c}1.20 \\
(\mathrm{nCi} / \mathrm{cc})\end{array}$ & Gamma ray at $6 \mathrm{MeV}$ \\
\hline $0-19$ & 26.9 & $1.20 \mathrm{E}+08$ & $1.29 \mathrm{E}+04$ & $\begin{array}{c}75.0 \\
(\mathrm{pCi} / \mathrm{cc})\end{array}$ & $\begin{array}{l}\text { Gamma ray at } 110,197 \text {, } \\
\text { and } 1357 \mathrm{keV}\end{array}$ \\
\hline F-20 & 11 & $1.20 \mathrm{E}+09$ & $5.29 \mathrm{E}+04$ & $\begin{array}{c}750 \\
\text { (pCi/cc) }\end{array}$ & Gamma ray at $1633 \mathrm{keV}$ \\
\hline
\end{tabular}




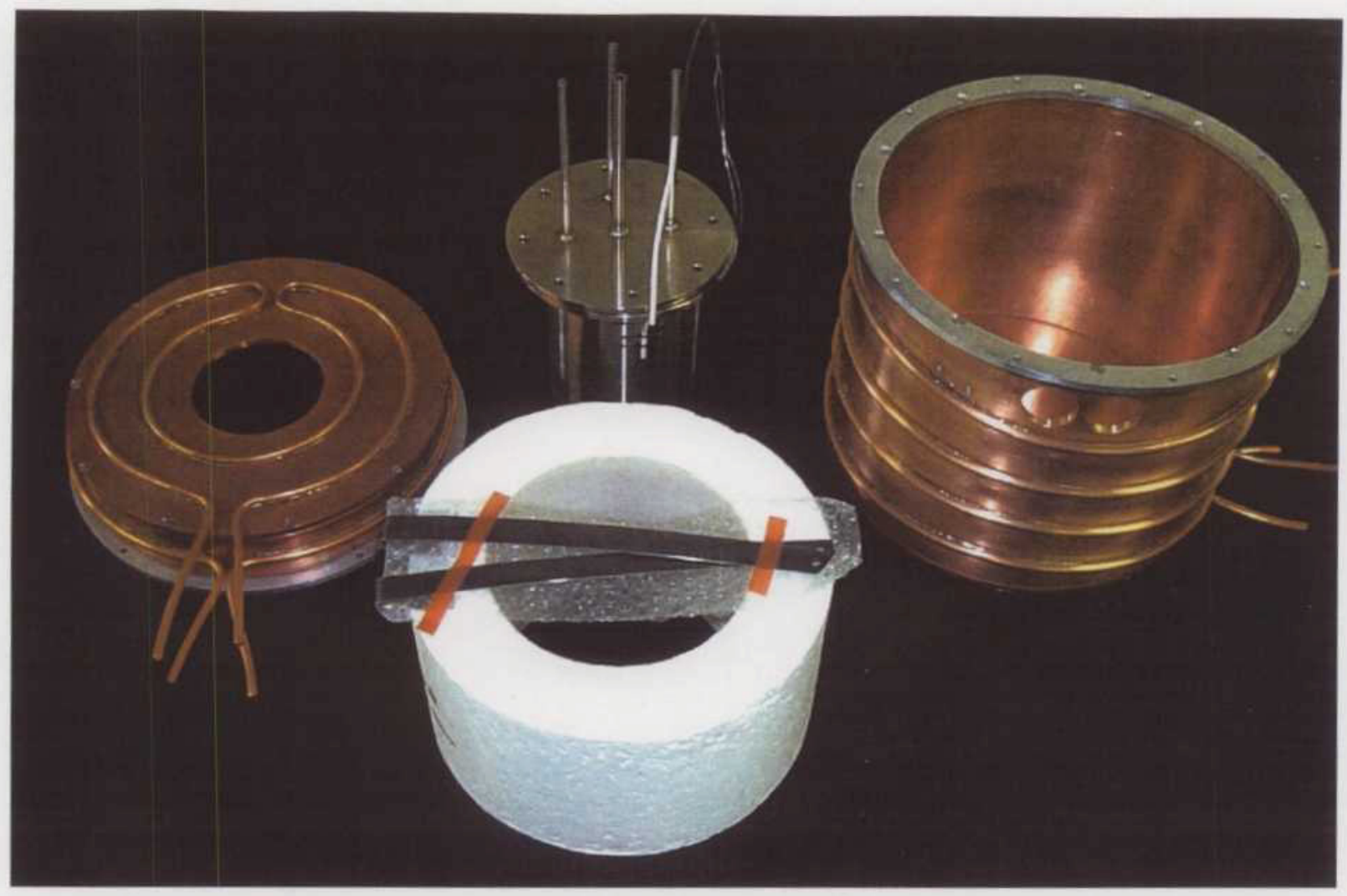

Figure 7. Primary test vessel and related hardware.

is set up inside a glovebox (Vacuum Atmospheres model GBX-002-D). A photograph of the glovebox is provided in Figure 6. External dimensions of the stainless-steel glovebox are: $2.3-\mathrm{m}$ (90-in.) long by $0.9-\mathrm{m}$ (36-in. high) with a base width of $1.2-\mathrm{m}(46-\mathrm{in}$.$) and a top width of 0.8-\mathrm{m}$ (32-in.) The glovebox has dual-sided access, with 8 gloveports on the 6-mm (0.24-in.) thick lexan windows. One end of the glovebox is equipped with a transfer chamber to provide for transfer of equipment and materials into and out from the glovebox in a way that does not compromise the internal atmosphere of the glovebox. The top and ends of the glovebox are equipped with penetrations to accommodate a variety of feedthroughs (electrical, gas line, water line, instrumentation leads, etc.). In addition, quadruplex electrical outlet boxes (110V ac) are attached to the interior end panels. These units are powered via hermetic electrical feedthroughs on the end panels, with junction boxes on the outside panels for connection to the electrical power supply.

The inert-gas glovebox has an associated atmosphere-cleanup and gas recirculation system (T. M. Vacuum products Model GD02400-02) that is not shown in the photograph. Connections between the glovebox and its associated cleanup/recirculation system are via hard plumbing (copper tubing) to isolation valves on the top of the glovebox, with an in-line HEPA filter in the outlet line of the glovebox. Inert-gas supply to the glovebox is managed by the gas-recirculation/control instrumentation. Exhaust from the re-circulation system is vented to the TRL glovebox and hood ventilation manifold. The glovebox atmosphere is typically maintained at a 


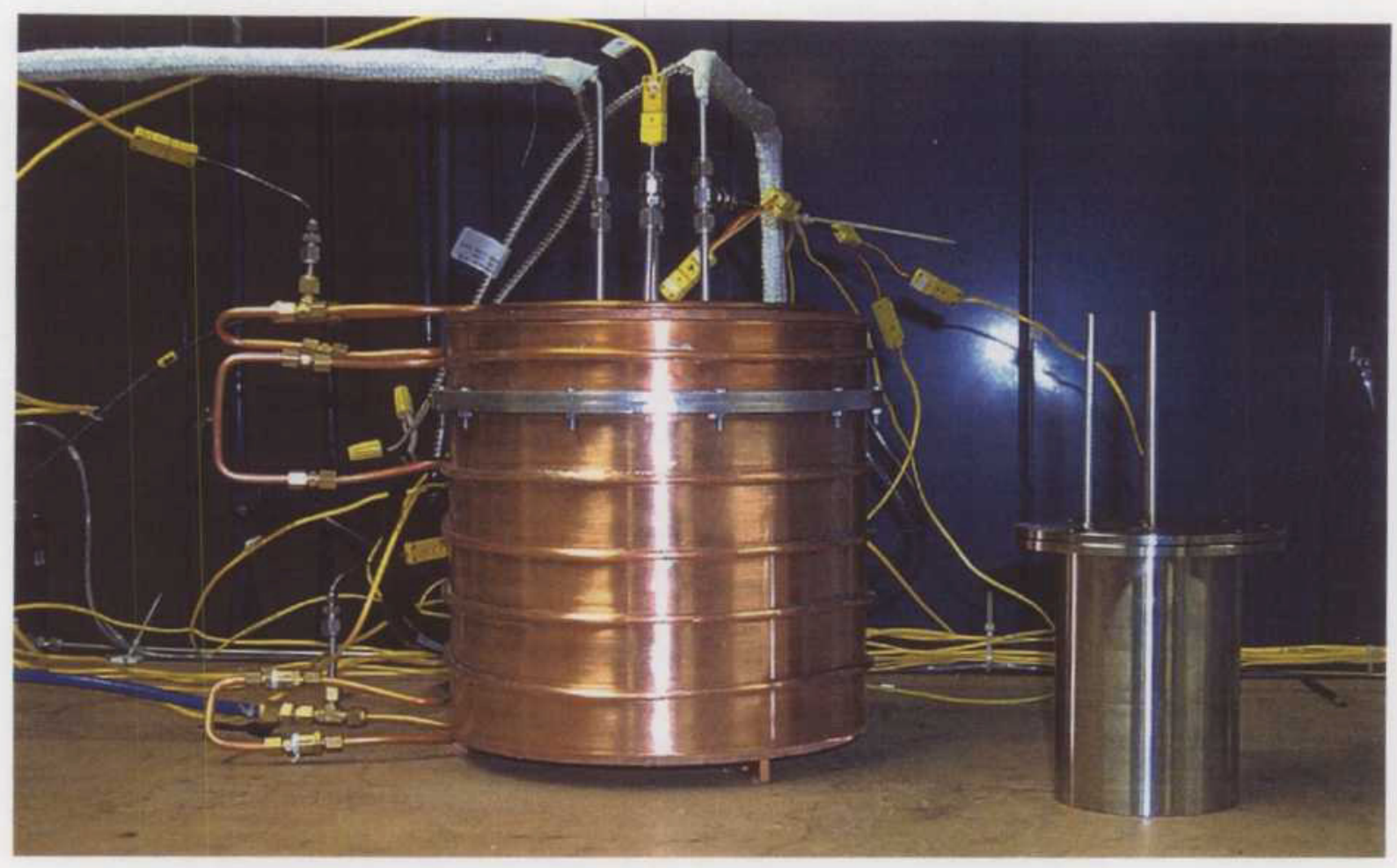

Figure 8. Preliminary test setup for Molten-salt Safety Experiment.

slight negative pressure, relative to the room air. High-purity helium is typically used as the glovebox atmosphere, although argon or nitrogen may also be used.

Service and process lines from control instrumentation outside the glovebox to the experimental apparatus inside the glovebox are made via the utility penetrations through the top and endpanels of the glovebox. The penetrations are threaded to accommodate a variety of feedthrus (fluid, electrical, instrumentation, tubing). Wherever possible, all tubing lines to and from the glovebox and within the glovebox environment will be made with stainless steel tubing, although tygon may be considered for the cooling water re-circulation to the cooling jackets surrounding the test and storage chamber heaters.

A photograph of the test vessel hardware is presented in Figure 7. The photograph shows the water-cooled copper housing, the ceramic-fiber heater and the stainless-steel test vessel with spot-welded thermocouple attached to the outer surface. Preliminary testing to date has included check-out of the primary and gas-line heaters and control systems, calibration and check-out of the mobilization gas-flow measurement instrumentation, and bake-out of the ceramic-fiber heaters to $1000^{\circ} \mathrm{C}$. A photograph of the preliminary experimental setup is provided in Figure 8 . In this photograph, the stainless-steel test cell is shown next to the water-cooled copper vessel. The insulated inlet and outlet gas lines and several thermocouples can also be seen in the photo. 


\section{CONCLUSIONS}

A viable design for the Fusion LIQUid Release Experiment (FLIQURE) has been developed at the INEEL. This experimental system is designed to measure the mobilization of tritium in molten Flibe under steady neutron irradiation at fusion-relevant temperatures $\left(500-1000^{\circ} \mathrm{C}\right)$. Trace neutron irradiation is achieved using a spontaneous fission ${ }^{252} \mathrm{Cf}$ source that produces a uniform production of tritium in the Flibe. The experimental goals aim to better understand the mechanisms, mobilization rates, and physiochemical forms of tritium in the Flibe along with other potentially detectable radioactive isotopes and toxic-material species under inert-gas, air, and steam-ingress conditions. Extensive neutronic analyses were performed in order to predict nuclear reaction rates in the Flibe and to develop FLIQURE geometry and material design options which would achieve a reasonably high tritium production rate while maintaining reasonable moderator and reflector size and mass. Reduction of the required mass of beryllium moderator material was one objective of the optimization. An optimal design presented in this paper achieves a volume-averaged neutron flux in the Flibe of $7.16 \mathrm{E}+6 \mathrm{n} / \mathrm{cm}^{2} / \mathrm{sec}$ while requiring only $157 \mathrm{~kg}$ of beryllium. The beryllium mass reduction was achieved by sleeving the ${ }^{252} \mathrm{Cf}$ source in a rectangular tube containing light water for neutron thermalization. Thermal/fluid design aspects of the FLIQURE experiment have also been presented. During testing, the Flibe $(1000 \mathrm{cc})$ will be contained in a cylindrical stainless-steel pot and heated to temperatures as high as $1000^{\circ} \mathrm{C}$ using an externally ceramic-fiber heater assembly. The Flibe will be subjected to various gas flows including inert gas, air, or steam. Hydrogen and tritium permeation through various materials will also be studied. Instrumentation for analysis of the mobilization and hydrogen-permeation gas streams will include a condenser unit to be used for condensation and collection of molten salt aerosol and vapor species that are transported in the gas stream flowing from the test chamber, a cascade impactor for aerosol collection and particle sizing, and a residual gas analyzer (RGA) for determination of gas composition. Preliminary testing on the unirradiated version of the FLIQURE experiment is already under way at the INEEL. 


\section{REFERENCES}

1. R.W. Moir et al., "HYLIFE-II Progress Report”, UCID-21816, December 1991.

2. L.C. Cadwallader and G.R. Longhurst, "Flibe Use in Fusion Reactors: An Initial Safety Assessment", INEEL/EXT-99-00331, Distribution Category: UC-425, March 1999.

3. A. Suzuki, T. Terai, S. Tanaka, "Change of tritium species in $\mathrm{Li}_{2} \mathrm{BeF}_{4}$ molten salt breeder under neutron irradiation at elevated temperature", Journal of Nuclear Materials 258-263 (1998) 519-524.

4. G.R. Longhurst, R.A. Anderl, and R.S. Willms, "Tritium Loss in Molten Flibe Systems", Proceedings of the $4^{\text {th }}$ IEA International Workshop on Beryllium Technology for Fusion", September 15-17, 1999, Karlsruhe, Germany, FZKA6462 Forschungszentrum, Karlsruhe and accepted for publication in Fusion Technology.

5. R.W. Moir et al., "HYLIFE-II: A Molten-Salt Inertial Fusion Energy Power Plant DesignFinal Report", Fusion Technology, Vol. 25, January 1994.

6. "MCNP4B: Monte Carlo N-Particle Transport Code System", LA-12625M, contributed by Los Alamos National Laboratory, Los Alamos, New Mexico, April 1997 and distributed as package CCC- 660 by Oak Ridge National Laboratory.

7. Labview Version 5.1, National Instruments, 1999. 